\title{
Designing Problem Based STAD Learning Models to Improve Students' Writing Skill
}

\author{
Wida Rianti', Citra Ayu², Putri Asilestari3 \\ DOI: $10.35445 /$ alishlah.v13i2.756
}

Article Info

Keywords:

Problem-Based STAD;

Learning Models;

Writing Skill

Kata kunci:

Model Pembelajaran;

STAD Berbasis Masalah;

Writing Skill

\begin{abstract}
This research was conducted to develop a learning model by using the ADDIE model. The problem-Based STAD learning model was designed by Analysis, Design, Development or Production, Implementation or Delivery, and Evaluations. This research was done in the English Language Education Study Program of the University of Pahlawan Tuanku Tambusai in Writing II. Based on the result of data analysis, it can be concluded that 1) The Problem-based STAD Type Learning Model has been produced through the ADDIE development model. 2) Problem-based STAD Type Learning Model that has met the criteria of validity. 3) The model is valid with the characteristics of the suitability of the research model development with the ADDIE procedure. English teachers can use this model to improve students' skills in writing and motivate the students in writing English text.
\end{abstract}

\begin{abstract}
Abstrak
Penelitian ini dilakukan untuk mengembangkan model pembelajaran dengan menggunakan model ADDIE. Model pembelajaran STAD Berbasis Masalah dirancang dengan proses Analisis, Desain, Pengembangan atau Produksi, Implementasi atau Penyampaian dan Evaluasi. Penelitian ini dilakukan di Program Studi Pendidikan Bahasa Inggris Universitas Pahlawan Tuanku Tambusai pada mata kuliah Penulisan II. Berdasarkan hasil analisis data dapat disimpulkan bahwa 1) Model Pembelajaran Tipe STAD-BM telah dihasilkan melalui model pengembangan ADDIE. 2) Model Pembelajaran Tipe STAD-BM yang telah memenuhi kriteria validitas. 3) Model dikatakan valid dengan ciriciri kesesuaian pengembangan model penelitian dengan prosedur ADDIE. Model ini dapat digunakan oleh guru bahasa Inggris untuk meningkatkan keterampilan siswa dalam menulis dan memotivasi siswa dalam menulis teks bahasa Inggris.
\end{abstract}

${ }^{1}$ Universitas Pahlawan Tuanku Tambusai, Bangkinang, Indonesia

Email: widia19aurora@gmail.com

2 Universitas Pahlawan Tuanku Tambusai, Bangkinang, Indonesia

Email: Citraayu1980@gmail.com

3 Universitas Pahlawan Tuanku Tambusai, Bangkinang, Indonesia

Email: putriasilestari89@gmail.com

Received: June 30, 2021; Received in revised form: July 27, 2021; Accepted: August 8, 2021; Available online: August 28, 2021

This is an open access article under a Creative Commons Attribution-NonCommercial-ShareAlike 4.0 International License 


\section{INTRODUCTION}

Learning English has been a strategic tool and strategy for human resource development in various nations' educational histories. The changes in the intensity of the challenges of the times and the demands of the interests of professionalism in life led to very dynamic changes in the learning orientation in this field. Currently, we are in the $21^{\text {st }}$ century marked by the rapid development of technology, so science and technology are some of the essential foundations in nation-building. Partnership for $21^{\text {st }}$ Century Skill (2013) as a reference for education states that competencies that need to be improved for students include core material, learning and innovation skills, information technology and media skills, life and career skills. This is in line with the principles of developing the 2013 Curriculum, which states that the learning process uses a scientific approach and assessment of learning outcomes based on processes and products through observing, questioning, exploring, associating, and communicating activities. It is also supported by the characteristics of the 2013 Curriculum as stated in the Basic Framework and Curriculum Structure designed to develop a balance between the development of spiritual and social attitudes, curiosity, and creativity, cooperation with intellectual and psychomotor abilities.

Learning English as a compulsory subject in Higher Education aims to help students learn and speak English. However, there are still many obstacles to teaching English in its implementation, both in Indonesia and other countries. Lack of teacher creativity in teaching English, the number of students in one class is significant. It limits the opportunities for students to practice English because the practice demands a long time and energy, the lack of quality English textbooks (Tabatabaei \& Pourakbari, 2012). The teacher faces another problem is teacher's ability to design learning, tasks, and teaching methods. Then, inadequate facilities for learning English, such as the learning environment and the availability of English learning resources, also influenced the learning process(Saeed et al., 2016). The differences in sentence structure in English also made it difficult to understand the concept in learning (Nourdad \& Asghari, 2017). The differences in language writing strategies, lack of awareness of students about the importance of proficiency in English, supporting from parents become some problems in teaching English (Kizildag, 2009).

Writing skill is one of the essential skills for students in Higher Education. In higher education, students must produce scientific works such as making research reports, papers, theses, theses, dissertations, and scientific journals. Writing is one of the four primary skills in learning English, including productive skills, focusing on language production. In simple terms, this writing can be interpreted as delivering messages (something to be said) through codes or signs written on paper. Producing work in good writing requires conveying information or messages effectively using meaningful sentences (Jayanti, 2019).

Learning writing is still learning that is quite difficult for students to master. In writing, all elements of linguistic knowledge are involved in producing a well-written work. In writing activities, writers must be skilled at utilizing graphology, sentence structure, and vocabulary. One example of a case such as research in Madiun shows that writing errors in learning writing are still high. The students still have errors in using appropriate tenses in writing sentences (Fadilah, 2019)

There are some problems in writing the text for the students. The problems are minor linguistic proficiency such as command over grammar, syntax, and vocabulary, writing anxiety, lack of ideas, reliance on L1, and weak structure organization (Fareed et al., 2016). While (Novariana et al., 2018) states that two kinds of students' problems; internal and external problems. The research shows that those problems are faced by students mostly in writing class.

The results of observations on implementing the writing learning class for the second semester have been conducted. The problems and difficulties of the students above, if not resolved, will become problems that hurt students in learning English, so we need a solution that can overcome student problems in learning. Designing a learning model is one solution that can be used to overcome these problems. The cooperative learning of Student Team Achievement Divison (STAD) model is a learning model that can activate students. This model provides opportunities for students 
to discuss and encourage student involvement in learning and emphasize activities and interactions between students and students to motivate each other and help understand a subject matter. (Slavin, 2015) explains that STAD is a learning model that shares ideas where students work together to learn and are responsible for peer learning and their own. These activities will create a good atmosphere for students to learn because they can work together in groups and depend on each other in the learning process.

The problem-based learning model is learning whose results are obtained through understanding a problem or getting a solution to a problem. (Tan, 2007) describes the problembased learning model as an active learning approach and progressive learning, which starts from unstructured problems or real-world problems. From the above opinion, it can be concluded that the problem-based learning model is recognized as the development of active learning and a learnercentered learning approach, which uses unstructured problems (real-world problems or complex simulation problems) as a point.

Some research was taken in using the STAD model in teaching and learning writing skills. (Novawan et al., 2020) state that the English teacher can use STAD to improve the students' ability to write a descriptive text. Then, another research by Nugroho (2013) also proved an improvement in students' writing skills after implementing STAD in teaching recount text. It can be seen that STAD can solve the students' problems in the writing process. This research develops a cooperative learning model (STAD model) combined with a Problem Based Learning Model (PBM) so that it is called the Problem Based STAD Type Model. This model emphasizes the cooperation of students in groups in understanding and solving a real problem to achieve learning goals and construct their knowledge according to their line of thought. The problem-based STAD type learning model is expected to bridge the problems in learning English because it provides opportunities for students to think actively, critically, and creatively to improve students' English skills, especially students' English writing skills. Through the problem-based STAD type learning model, students are involved in authentic problem-solving activities in groups and provide opportunities for students to work together in solving a problem.

\section{METHODS}

This research was conducted using the ADDIE model for Analysis, Design, Development or Production, Implementation or Delivery, and Evaluations (Branch, 2009). The analysis includes a needs analysis consisting of lecturer interviews with three lecturers, student interviews with curriculum analysis, concept analysis, and analysis of student characteristics. The results of the analysis can be used to formulate a management plan for solving problems that occur. The activities carried out are designing learning by the results of the needs analysis, namely the problem-based type STAD learning model book, the English teaching guide (learning device) using the problembased STAD type learning model in the form of a semester learning plan (RPS) and teaching materials/learning modules. English uses a problem-based STAD learning model. At the development stage, produce and validate development products. Then make a formative revision and conduct a limited test for practicality and effectiveness testing. In the implementation stage, the products implemented are teaching guides and teaching materials / English learning modules based on the principles of the problem-based STAD Type learning model. During implementation, the design of the model that has been developed is applied to the actual conditions to determine the practicality and effectiveness of the problem-based type STAD learning model. In the evaluation stage, an assessment of the quality of development products and processes is carried out both before and after implementation. This process has several main stages, including; assess the quality of the development process, the quality of the product developed, and then revise the learning model according to the expected learning objectives. 


\section{FINDINGS AND DISCUSSION}

\section{Analysis Phase}

The initial stage in this development research, which is called analysis, includes several activities. These activities include lecturer interviews, student interviews, curriculum analysis, concept analysis, and analysis of student characteristics. The interviews with professors showed that the learning device used in modules and lesson plans were used before entering college. It is not always updated in the early semester. The learning tools used so far are felt to need innovations so that students are more motivated. The three lecturers used their modules. Meanwhile, the interviews with students show that three students like to study in groups because they can exchange ideas with fellow students in completing assignments. In contrast, one student prefers to lecture because not all group members are willing to learn actively. In line with the lecturer's answer, all interviewed students stated that the learning tools used so far are quite helpful in learning but have not been maximal in supporting students' writing skills. The students think that there needs to be a learning model that supports the interaction of fellow students and the interaction of students with lecturers. All students admit that it is still challenging to start drafting; students still have difficulty transforming topics into written drafts. All interviewed students admitted that the writing process was complicated for students to do at the drafting stage.

The Writing II course's curriculum analysis shows that the composition of the material before the change consists of too much material accumulation for writing ideas, even to the point of being designed for six meetings. This condition is feared to make learning ineffective and boring, so it cannot increase student learning motivation. Then, the material makeup is formulated to support the model of problem-based learning STAD. However, due to the limited time of this research, the material prepared is still limited to five meetings. The concept analysis shows that the concept map describes the hierarchical material taught in the Writing II lecture process. The material presented for this writing course is arranged in sequence to guide students towards specific learning outcomes. The concept analysis in writing skills is the Concept Map Introductory Sentence, Concept Map Topic Sentence, Concept Map Supporting Sentence, and Concept Map Concluding Sentence.

Furthermore, the analysis of the characteristics of students of the S1 English Education Study Program at Pahlawan Tuanku Tambusai University showed that 100 percent of students were fresh graduates from high school. The characteristics of students seen in their writing abilities are quite varied. Only two statement items received high scores, including 60\% ability to plan writing based on daily life, 30\% understanding of the mechanics of paragraph preparation, $40 \%$ analyzing daily problems in writing assignments, and 60\% detecting errors in paragraph writing. Fourteen students liked group learning because, according to them, achieving maximum results in carrying out tasks required collaboration with colleagues, while the remaining six people did not like groups. A total of 16 students admitted that they were interested in learning writing related to daily life problems. In presenting new ideas in discussion activities, all students tend to look at topics on the internet that tell about everyday life and are familiar with their lives. However, to come up with ideas for writing paragraphs that they will compile, students still have difficulty because of the habit of writing paragraphs in English that have not been trained.

\section{Design Phase}

A model framework is prepared in available products at the design stage, such as model books, lecturer books, and student books. The framework of the model book, lecturer book, and student book is explained as follows:

a. Model Book

The model book consists of several parts, such as 1) Cover. The design of the model book is carried out, starting from the cover design, letter selection, spacing to the content of the model book. 2) Letters and Spaces. The font chosen for the model book is Times New Roman. Spaced typing on a book that is chosen is 15 spaces. 3) Systematic. The model book comprises several sections, such as the introduction and the table of contents at the beginning. The content section 
consists of rational models, model components, and cover. The closing section consists of conclusions and suggestions. In the end, there is a bibliography which is a reference source for model books.

b. Lecturer's Book

The cover is set differently from the model book to make it easier to distinguish the type of book. The letters chosen for the lecturer's book are the same as the model book, namely the time new roman font, and the typing is done in 1 space. In the beginning, there is an introduction and a table of contents. The first part of the book is equipped with a guide for using the lecturer's book. The load is on the syllabus, lesson plan, lesson plans, teaching materials, student activity observation sheet, and scoring rubric.

c. Student Book

Making is done by paying attention to the difference between model books and lecturer books. The letters chosen for the lecturer's book are the same as the model book and the lecturer's book, namely the time new roman font to provide uniformity of letters in the three-book products produced. In the beginning, there is a preface and table of contents, and a guide to the use of student books. The content section contains learning materials equipped with questions and learning examples, group and individual assignments, and reflection notes.

\section{Development Phase}

\section{a. Drafting}

The researcher, as the author tries to design their design beginning of the cover, can be seen as follow:
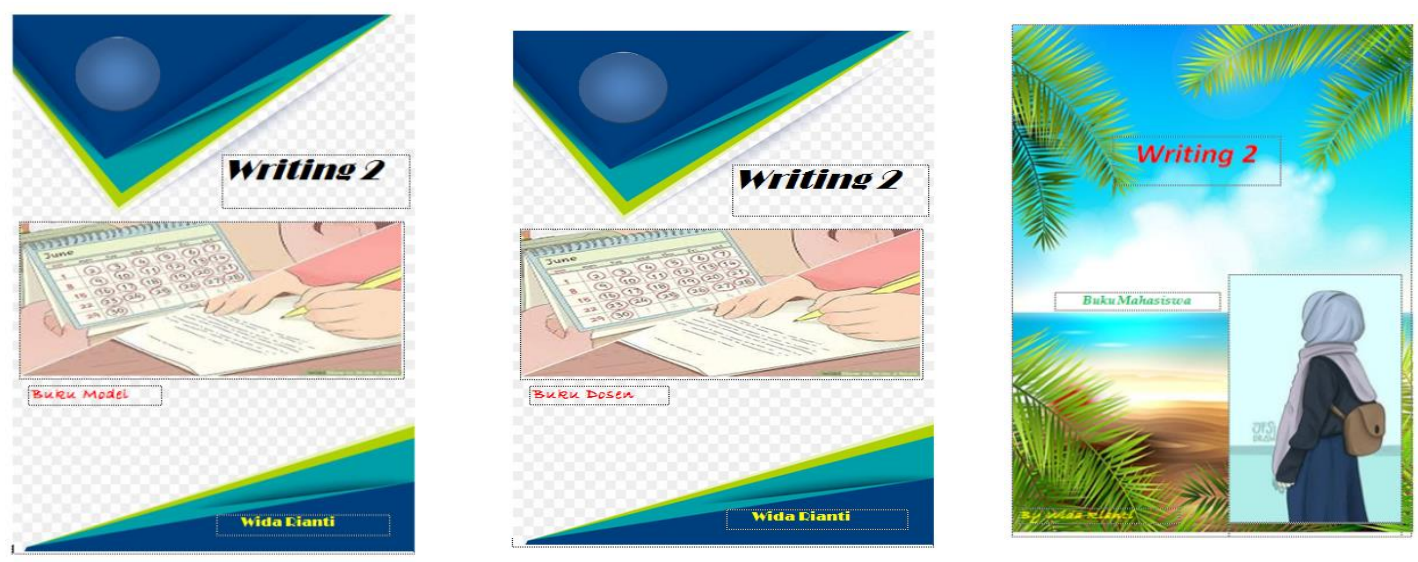

Figure 1 . Cover of Model Books, Lecturer Books, and Student Books

The model book is written so that lecturers can easily understand it to be applied to writing learning in universities. The rational model describes the needs and reasons for developing the model. The model components consist of the initial model syntax and the model syntax after it was developed, the social system that describes the interaction of lecturers and students during learning, reaction principles, support systems, instructional impacts, and accompaniment impacts.

\section{b. Self-Evaluation}

Evaluation needs to be done by the researchers themselves as an initial correction to the product design that has been prepared. Aspects evaluated in self-evaluation are divided into three parts: self-evaluation of model books, lecturer books, and student books. In general, based on the model book's self-evaluation results, all corrected components were supporting theory, syntax, social system, reaction principle, support system, instructional impact and accompaniment impact, implementation of learning model, language, and graphics. 
c. Expert Review of Model Books

The results of the expert assessment are presented in several tables, which are presented separately according to the assessment category. The assessment interval in each category is different because the number of items in the assessment statement is different. For more details can be seen as follows.

1) The graphic category's assessment consists of three categories: book size, cover design, and content design. A recapitulation assessment expert can be seen in table 1 . The average rating expert for 28,33 indicates that the model for the graphic book category pertained to the value of $\mathrm{B}$, which can be used with minor revision. Revisions are made by the expert suggestions, as shown in the following table.

Table 1 . Expert Advice for the Graphics Category of Model Books

\begin{tabular}{|c|c|}
\hline Expert & Suggestion \\
\hline \multirow[t]{2}{*}{$\mathrm{IZ}$} & Adjust book size \\
\hline & Cover design to fix using photoshop \\
\hline \multirow[t]{2}{*}{ FQ } & Book size to be reduced. \\
\hline & Choose a cover color to make it more attractive \\
\hline \multirow[t]{2}{*}{ JR } & Cover to be repaired more attractive \\
\hline & $\begin{array}{l}\text { The typeface to be distinguished from research reports to describe the } \\
\text { characteristics of your product }\end{array}$ \\
\hline
\end{tabular}

2) Assessment of linguistic categories, consisting of three aspects. In this category, the language in question is Indonesian, as described in the following table. Average rating experts on linguistic categories by 11 are classified as value $\mathrm{B}$, meaning a book in language models can be used with minor revision. Revision for the linguistic category.

Table 2. Expert Advice for Language Category

\begin{tabular}{cl}
\hline Expert & Suggestion \\
\hline NM & Check again for typing errors \\
MS & Pay attention to the writing of sentences and adjust them according to \\
& $\begin{array}{l}\text { Indonesian grammar rules tata } \\
\text { The use of terms needs to be re-checked } \\
\text { JR }\end{array}$ \\
& $\begin{array}{l}\text { Re-check a few sentences in the book so that readers can easily } \\
\text { understand them }\end{array}$ \\
\hline
\end{tabular}

3) Expert assessment of the model book for the learning category, based on six indicators. The recapitulation of expert assessments can be seen in the following table. The result of the expert assessment of the model book for the learning category is 162 (B value), which means that the model book can be used with a slight revision to the model book from the learning aspect. Suggestions from experts in the learning category are presented in the following table: 
Table 3. Expert Suggestions for Learning Categories

\begin{tabular}{|c|c|}
\hline Expert & Suggestion \\
\hline MS & $\begin{array}{l}\text { 1. Clarify the syntax difference between the original model } \\
\text { and the developed model } \\
\text { 2. Check back the supporting theory for more details } \\
\text { 3. Improve description of model component elements }\end{array}$ \\
\hline $\mathrm{NM}$ & $\begin{array}{l}\text { 1. The difference in syntax between the original model and } \\
\text { the developed model must be clear } \\
\text { 2. Pay attention to the role of the lecturer as a motivator, } \\
\text { especially in daily life problems } \\
\text { 3. Clarify the role of lecturers in each phase and clarify the } \\
\text { assessment process } \\
\text { 4. Clarify the scope of instructional impact }\end{array}$ \\
\hline MW & $\begin{array}{l}\text { 1. Re-examine relevant theories to support model } \\
\text { development } \\
\text { 2. Make sure that the syntax describes the novelty of the } \\
\text { developed model } \\
\text { 3. Clarify the activities of the lecturer's reflection stage } \\
\text { 4. Pay attention to the scope of the model support system } \\
\text { and the suitability of the material with the learning } \\
\text { indicators }\end{array}$ \\
\hline
\end{tabular}

d. Expert Review of Lecturer Books

1) The results of the expert assessment of the lecturer's book are based on the graphic category. The assessment for the graphic category in the lecturer's book includes: The results of the expert assessment are described in table 4. The result of the expert assessment is 29 , which is in category $\mathrm{B}$, which can be used with a bit of revision.

Table 4 • Expert Suggestions for Lecturer's Book Graphic Category

\begin{tabular}{cl}
\hline Expert & Suggestion \\
\hline IZ & $\begin{array}{l}\text { 1. Adjust book size } \\
\text { 2. Cover design to make it even more attractive }\end{array}$ \\
LW & $\begin{array}{l}\text { 3. Improve the use of type and font variations and layout } \\
\text { 2. Improve the appearance of the cover to make it more } \\
\text { JR }\end{array}$ \\
& $\begin{array}{l}\text { 1. The size of the book to adjust to the provisions for a } \\
\text { research product (if there are standard provisions) }\end{array}$ \\
& 2. Cover design made even more attractive
\end{tabular}

2) The results of the expert assessment of the lecturer's book are based on the linguistic category. The expert assesses the linguistic category in the lecturer's book, as shown in the following table. The results of the expert assessment are classified as B with an average score of 11, which means that there needs to be a slight revision in the linguistic category. Suggestions from experts that are used as a starting point for improvement are as follows.

Table 5. Expert Suggestions for Lecturer Book Language Category

\begin{tabular}{cl}
\hline Expert & Suggestion \\
\hline NM & Check again for typing errors \\
MS & Double-check the terms used \\
JR & Avoid using sentences that are not effective \\
\hline
\end{tabular}

3) The results of the expert assessment of the lecturer's book are based on the learning category. The results of the expert assessment are listed in table 
6. The expert assessment in the learning category for lecturer books is also classified as a B value. From a linguistic perspective, several items need a minor revision. Expert suggestions for the learning category in the lecturer's book are as follows.

Table 6. Expert Suggestions for Lecturer Book Learning Category

\begin{tabular}{cl}
\hline Expert & \multicolumn{1}{c}{ Suggestion } \\
\hline MS & $\begin{array}{l}\text { Check the steps of the lecturer's activities again as } \\
\text { mentors, facilitators, and evaluators } \\
\text { Make sure again that the lecturer's book is loaded to } \\
\text { increase students' motivation, attitudes, and } \\
\text { mathematical abilities } \\
\text { Pay attention to the suitability of the time allocation for } \\
\text { the implementation of learning with the material } \\
\text { provided } \\
\text { Make sure again that the activities carried out by the } \\
\text { lecturer are by the syntax of the problem-based STAD } \\
\text { type learning model }\end{array}$ \\
\end{tabular}

4) Content category assessment consists of two aspects, namely content feasibility. The results of the content field assessment can be seen in table 7. The expert's assessment of the category of lecturer's book content is 15 , which belongs to the B value interval; because the expert believes that several improvements must be made to the content of the lecturer's book. In the following table, there are some expert suggestions for lecturer books for content categories.

Table 7. Expert Suggestions for Lecturer Book Content Category

\begin{tabular}{cl}
\hline Expert & \multicolumn{1}{c}{ Suggestion } \\
\hline AL & $\begin{array}{l}\text { Check the completeness and description of the material so that it is easy } \\
\text { to understand }\end{array}$ \\
YT & $\begin{array}{l}\text { The material must be adjusted again by referring to relevant textbooks } \\
\text { and pay attention to the writing of symbols and pictures }\end{array}$ \\
MS & Materials to be more characterized in the PB-STAD Type Learning Model \\
\end{tabular}

e. Expert Review of Student Books

Like lecturer books, expert assessments of student books also cover the categories of graphics, language, learning, and content. The results of the assessment and expert suggestions are described as follows.

1) The results of the expert assessment of the lecturer's book are based on the graphic category. The recapitulation of expert assessment is more clearly described in the following table. The results of the expert assessment of student books reached an average of 14 , which is also included in the B value interval, so for this graphic category, it is necessary to revise it. In the following table, expert suggestions are presented on student books for the graphic category.

Table 8. Expert Advice for the Graphics Category Student Book

\begin{tabular}{ll}
\hline \multicolumn{1}{c}{ Expert } & \multicolumn{1}{c}{ Suggestion } \\
\hline DM & Illustrations of the book to make it more interesting \\
LW & A4 size is too big for a book \\
& Improve the appearance of the cover to make it more \\
& attractive \\
JR & Book size to make it in a simpler size
\end{tabular}

2) The results of the expert assessment of student books based on linguistic categories. The results of the expert assessment are described in the table 9. The assessment of the linguistic category gets a B value with an average score of 24 , which means that it needs 
improvement as suggested by the expert. Expert suggestions can be seen in the following table.

Table 9. Expert Suggestions for the Language Category of Student Books

\begin{tabular}{cl}
\hline Expert & \multicolumn{1}{c}{ Suggestion } \\
\hline NM & $\begin{array}{l}\text { Consistency in the use of terms and symbols needs to be } \\
\text { considered } \\
\text { Pay attention to the use of notations/symbols in the book, } \\
\text { as well as the use of proper language } \\
\text { The use of symbols needs to be considered } \\
\text { Pay attention to the writing of sentences, adjust them } \\
\text { with good and correct grammar rules }\end{array}$ \\
\hline
\end{tabular}

3) The results of the expert assessment of student books based on learning categories. The results of the assessment can be seen in table 10. Assessment from the expert is needed to guide the student's learning category and other categories, classified as a $B$ with an average value expert of 30, 33. It needs to be revised with expert suggestions. Details of expert advice on the linguistic category in the student book are as follows.

Table 10. Expert Advice for Learning Categories Student Book

\begin{tabular}{ll}
\hline Expert & \multicolumn{1}{c}{ Suggestion } \\
\hline MS & $\begin{array}{l}\text { Strive to use pictures and illustrations of the material so that it attracts } \\
\text { the attention of students to understand the material presented } \\
\text { Try to make the problem presented is a hot topic of discussion at this time }\end{array}$ \\
NM & $\begin{array}{l}\text { The continuity of the material should be checked again to make it easier for } \\
\text { students to understand the material from beginning to end }\end{array}$ \\
MW & $\begin{array}{l}\text { Revision: } \\
\text { Checking and correcting the use of inappropriate images and material presented in student } \\
\text { books }\end{array}$
\end{tabular}

4) Content category assessment consists of two aspects, namely content feasibility. The results of the content field assessment can be seen in table 11. Based on the assessment results in the category of student book content, the average expert's assessment is 39. The results of the expert assessment of student book content get a B value so that the category of student book content requires revision suggested by the expert.

Table 11. Expert Advice for Student Book Content Category

\begin{tabular}{cl}
\hline Expert & \multicolumn{1}{c}{ Suggestion } \\
\hline AM & $\begin{array}{l}\text { Pay attention to the depth of the material and the } \\
\text { breadth of the material so that it is maximal for } \\
\text { students to understand } \\
\text { YT }\end{array}$ \\
Complete the matter by referring to books relevant \\
basic material n \\
The concept of facts and principles must be clear and \\
the material should be arranged according to the \\
syntax of the PB-STAD Type Learning Model
\end{tabular}

Suggestions from experts become valuable input for product revision to make it better. Several changes were made, primarily related to the addition of the PB-STAD Type Learning Model syntax table, improving the composition of teaching materials. In the following expert assessment table, the data presented summarizes the results of the recapitulation of the expert assessment consisting of various aspects and indicators. 
Table 12. Expert Assessment Validation Results on Products

\begin{tabular}{|c|c|c|c|c|c|c|}
\hline No & Aspect & Book & Average Expert score & $\begin{array}{l}\text { Number of } \\
\text { statements }\end{array}$ & $\begin{array}{l}\text { Average } \\
\text { Score }\end{array}$ & Criteria \\
\hline \multirow{3}{*}{1} & \multirow{3}{*}{ Graphics } & Model & 28.33 & 8 & 3.54 & \multirow{3}{*}{ Valid } \\
\hline & & Lecturer & 29 & 8 & 3.63 & \\
\hline & & $\begin{array}{l}\text { College } \\
\text { student }\end{array}$ & 30 & 8 & 3.75 & \\
\hline \multirow{3}{*}{2} & \multirow{3}{*}{ Language } & Model & 11 & 3 & 3.56 & \multirow{3}{*}{ Valid } \\
\hline & & Lecturer & 11 & 4 & 2.75 & \\
\hline & & $\begin{array}{l}\text { College } \\
\text { student }\end{array}$ & 24 & 6 & 4.00 & \\
\hline \multirow{3}{*}{3} & \multirow{3}{*}{ Learning } & Model & 162 & 41 & 3.95 & \multirow{3}{*}{ Valid } \\
\hline & & Lecturer & 27 & 7 & 3.86 & \\
\hline & & $\begin{array}{l}\text { College } \\
\text { student }\end{array}$ & 30.33 & 8 & 3.79 & \\
\hline \multirow[b]{2}{*}{4} & \multirow[b]{2}{*}{ Content } & Lecturer & 15 & 4 & 3,75 & \multirow[t]{2}{*}{ Valid } \\
\hline & & $\begin{array}{l}\text { College } \\
\text { student }\end{array}$ & 39 & 11 & 3,55 & \\
\hline \multicolumn{5}{|c|}{ Total average } & 3,65 & Valid \\
\hline
\end{tabular}

Based on table 12, it is known that the expert's assessment of model books, lecturers' books, and student books is considered valid. Therefore, the criteria in this development for the valid category have been met. For the level of intra-class correlation coefficient on testing the validity of the research instrument, the results of the SPSS output are as follows.

Table 13. Reliability Test Results

\begin{tabular}{cc}
\hline $\begin{array}{c}\text { Cronbach's } \\
\text { Alpha }\end{array}$ & N of Items \\
\hline 0.786 & 3 \\
\hline
\end{tabular}

Cronbach's alpha value was obtained at $0.786>0.05$, so it can be said that the existing product meets the reliable criteria. Furthermore, for the Interclass Correlation Coefficient (ICC) test, the SPSS output is obtained as follows.

Table 14. ICC Test Results on Products Intraclass Correlation Coefficient

\begin{tabular}{|c|c|c|c|c|c|c|c|}
\hline & \multirow[t]{2}{*}{$\begin{array}{l}\text { Intraclass } \\
\text { Correlation } \mathrm{b}\end{array}$} & \multicolumn{2}{|c|}{$\begin{array}{l}\text { 95\% Confidence } \\
\text { Interval }\end{array}$} & \multicolumn{4}{|c|}{ F Test with True Value 0} \\
\hline & & $\begin{array}{l}\text { Lower } \\
\text { Bound }\end{array}$ & $\begin{array}{l}\text { Upper } \\
\text { Bound }\end{array}$ & Value & df1 & df2 & Sig \\
\hline $\begin{array}{l}\text { Single } \\
\text { Measures }\end{array}$ & $.534^{a}$ & -124 & .955 & 4.419 & 3 & 6 & .059 \\
\hline $\begin{array}{l}\text { Average } \\
\text { Measures }\end{array}$ & $.786^{c}$ & -.493 & .985 & 4.419 & 3 & 6 & .059 \\
\hline
\end{tabular}

In the table of ICC test results, it is known that the ICC value is 0.786 . This can be interpreted that the experts have a high level of consistency in assessing the product. This research resulted in a new learning model, namely the PB-STAD Type Learning Model. This model has gone through a process to get conclusions about validity, practicality, and effectiveness. The study results show that the model developed, namely the PB-STAD Type Learning Model, has met the valid, practical, and effective criteria. The PB-STAD Type Learning Model development produces model books, lecturer books, and student books. Validation is an aspect of product quality produced and measured from an expert's point of view. The products produced in developing the PB-STAD Type Learning Model consist of model books, lecturer books, and student books.

Validation of the model is done by looking at three aspects, namely aspects of graphics, language, and learning. The assessed three aspects get a B value, which can be used with a bit of 
revision. Revisions are made according to expert advice. The expert assessment shows that, in general, the model books that have been carried out have met the valid categories. Suggestions from experts are needed to develop the model that is carried out so that it is by the rationale and the characteristics and theoretical basis that support it. The rational model presented in the model book reveals the importance of developing the PB-STAD Type Learning Model. STAD is a simple collaborative learning model in which small groups of students with various ability levels work together, presenting objectives, materials, quiz discussions, and team achievements (Deswarni, 2018). The components in the model developed are by (Bruce Joyce, Marsha Weil, 2011) include syntax, reaction principles, social systems, support systems, and instructional impacts. The PBSTAD Type Learning Model supports the behaviorism learning theory based on Skinner's (1953) (Malone, 1975) opinion. Skinner makes reinforcement the heart of learning, and lecturers reinforce students to obtain the desired behavior. Another theory is cognitivist, which in this case is a focus on constructivism. (Schunk, 1986) suggested a constructivism approach that was successfully applied in learning writing.

The lecturer's book contains learning tools and materials being taught. Therefore, the expert assessment of the lecturer's book is carried out on four aspects, namely aspects of graphics, language, learning, and content. The results of the expert's assessment of the lecturer's book in these four aspects are classified in the B value interval, which can be used with a little revision. The revisions were related to sentences, the book's size, and the clarity of the activity steps in learning and content supporting the PB-STAD Type Learning Model. The lecturer's book contains the activities of lecturers in learning which are based on the PB-STAD Type Learning Model. As an educator, lecturers must learn to increase students' knowledge and improve their social skills. By the opinion of (Slavin, 2015), in this model, the lecturer gives group rewards, controls students to be individually responsible for completing assignments, and ensures collaboration goes well in small groups.

Aspects assessed in student book validation are the same as aspects assessed in lecturer books, namely graphics, language, learning, and content. The difference is that there is a syllabus and lesson plans in the lecturer's book, while it is not loaded in the student's book. The results of the expert assessment of student books are classified as B grade interval categories can be used with slight revisions. Revisions are made by expert advice. Revisions were made to make this book more accessible for students to understand the material being studied. Based on the results of the discussion of the results of the validity test of the PB-STAD Type Learning Model, it can be concluded that the model books, lecturer books, and student books are feasible to use. The validation carried out by these experts is consistent, supported by the results of SPSS output, where the ICC value is 0.786. This is by (Branch \& Gustafson, 1999) opinion that the learning model is valid if the model development is by procedures and is based on the field of knowledge and theory of the development of teaching materials. Expert assessment is supported by implementing formative evaluation proposed by Tessmer (Plomp \& Nieveen, 2013) that products that experts have validated have a better resistance level than other techniques. The validity refers to the level of intervention design based on the state of the art knowledge and the various components of the intervention related to each other.

\section{CONCLUSION}

The development of the PB-STAD Type Learning Model and systems supports the model in lecturers and student books. Based on the discussion of the research results, it can be concluded that the PB-STAD Type Learning Model has been produced through the ADDIE development model. PBSTAD Type Learning Model that has met the criteria of validity. The model is valid with the characteristics of the suitability of the research model development with the ADDIE procedure. The research is limited to PB-STAD Type Learning Model in teaching writing skills. It also can be used for further research on other language skills in English teaching and the learning process. 


\section{REFERENCES}

Branch, R. M., \& Gustafson, K. (1999). Design Approaches and Tools in Education and Training. Design Approaches and Tools in Education and Training. https://doi.org/10.1007/978-94011-4255-7

Bruce Joyce, Marsha Weil, E. C. (2011). Models of Teaching (Eight Edition*). 478.

Deswarni, D. (2018). The Effect of Using STAD Strategy Toward Students' Reading Comprehension. Al-Ishlah: Jurnal Pendidikan, 10(1), 116-130.

Fadilah, F. (2019). an Error Analysis of Simple Past Tense in Writing of State Smk in Jakarta. Wanastra: Jurnal Bahasa Dan Sastra, 11(1), 15-24. https://doi.org/10.31294/w.v11i1.4913

Fareed, M., Ashraf, A., \& Bilal, M. (2016). ESL Learners' Writing Skills: Problems, Factors and Suggestions. Journal of Education \& Social Sciences, 4(2), 83-94. https://doi.org/10.20547/jess0421604201

Jayanti, A. D. (2019). Students' Writing Ability on English Descriptive Text at Grade VIII in SMPN 3 Padang. English Franca, 3(1), 71. https://core.ac.uk/download/pdf/237014945.pdf

Kizildag, A. (2009). Teaching English in Turkey: Dialogues with Teachers about the Challenges in Public Primary Schools. International Electronic Journal of Elementary Education, 1(3), 188201.

https://search.ebscohost.com/login.aspx?direct=true\&db=eric\&AN=EJ1052035\&site=ehostlive

Malone, J. C. (1975). William James and B. F. Skinner: behaviorism, reinforcement, and interest. Behaviorism, 3(2), 140-151.

Nourdad, N., \& Asghari, R. (2017). The Effect of Reflective Reading on Reading Comprehension of Iranian EFL Learners. International Journal of Applied Linguistics and English Literature, 6(6), 267. https://doi.org/10.7575/aiac.ijalel.v.6n.6p.267

Novariana, H., Sumardi, \& Tarjana, S. S. (2018). Senior High School Students' Problems in Writing A Preliminary Study of Implementing Writing E-Journal as Self Assessment to Promote Students' Writing Skilla. English Language and Literature International Conference (ELLiC), 2, 216-219. jurnal.unimus.ac.id

Novawan, A., Aisyiyah, S., Miqawati, A. H., Wijayanti, F., \& Indrastana, N. S. (2020). JER| Journal of ELT Research. 5(1), 80-93. https://doi.org/10.22236/JER

Nugroho, M. B. (2013). the Implementation of Stad 72,03529(678'(176 Ability in Writing Recount Text At the First Grade of Sman 3 Bandar Lampung. Journal of Chemical Information and Modeling, 53(9), 1689-1699.

Plomp, T., \& Nieveen, N. (2013). Educational Design Research Educational Design Research.

Saeed, N. R., Jordan, A.-, \& Jafar, F. A. A. (2016). Problems of Teaching English in Iraqi Public Schools in Mosul for the Intermediate Stage from the Teachers 'Point of View Amman Arab University. 6(1), 53-60.

Schunk, D. H. (1986). Experimental speculations. In Nature (Vol. 322, Issue 6078). https://doi.org/10.1038/322399bo

Slavin, R. E. (2015). Instruction Based on Cooperative Learning. Handbook of Research on Learning and Instruction, January 2011. https://doi.org/10.4324/9780203839089.ch17

Tabatabaei, O., \& Pourakbari, A. A. (2012). An Investigation into the Problems of Teaching and Learning English in the Isfahan Province High Schools, Iran. Journal of Language Teaching and Research, 3(1), 102-111. https://doi.org/10.4304/jltr.3.1.102-111

Tan, O. S. (2007). Problem-based learning pedagogies: Psychological processes and enhancement of intelligence. Educational Research for Policy and Practice, 6(2), 101-114. https://doi.org/10.1007/s10671-007-9014-1

Tiantong, M., \& Teemuangsai, S. (2013). Student team achievement divisions (STAD) technique through the moodle to enhance learning achievement. International Education Studies, 6(4), 85-92. https://doi.org/10.5539/ies.v6n4p85 